\title{
1. Meaning and form in international law
}

International law's words, idioms, aphorisms, and texts - what are called here the forms of the international legal discourse - are commonly thought as representing and referring to some pre-existing meaning. Indeed, it is ordinary to bestow on the forms of the international legal discourse a signifying function whereby such words, idioms, aphorisms, and texts represent a thing, an idea, a norm, a practice, a behavior, an institution, a discourse, and so on. According to this dominant meaning-centric understanding, meaning necessarily pre-exists the form that is derived from it, for it is only if the meaning precedes the form that the form can come to represent that meaning. In short, in international legal thought and practice, meaning is deemed the cause and origin of forms.

This book challenges the meaning-centrism of international legal thought and practice. It argues that the forms of the international legal discourse cannot find their origin or cause in some pre-existing meaning, for the latter is always absent. This book particularly shows that meaning is nowhere to be found and always absent from the forms of the international legal discourse because it is constantly deferred by them. According to the argument developed in this book, the absence of meaning from the forms of the international legal discourse bears important consequences. Indeed, the forms of the international legal discourse, finding neither their cause nor origin in any preceding meaning, do not need meaning to do what they do but only need other forms. Forms are accordingly the real sovereign of international legal thought and practice. This book is a venture into the sovereignty of forms and its implications for international legal thought and practice.

This chapter starts by describing the dominant meaning-centric attitude witnessed in international legal thought and practice (1) as well as the three main modes of thinking associated with it (2). This chapter then spells out the main argument of this book, namely that the forms of the international legal discourse are sovereign in that they do not carry or delivery any pre-existing meaning but constantly defer meaning (3). Although this will be the object of the last part of the book, this chapter already sketches out some of the main implications of the sovereignty of forms for international legal thought and practice (4). This chapter ends with a few observations on the contents of this book as well as a few caveats about the argument developed therein (5). 
Before elucidating the meaning-centrism of international legal thought and practice, a preliminary remark is in order. As it is understood here, the meaning-centrism of international legal thought and practice corresponds to a well-known and more general pattern of thought that is called logocentrism. ${ }^{1}$ It should accordingly be no surprise that the following exposition of meaning-centrism of international legal thought and practice makes use of the categories that have been used to described logocentrism in literary theory and critical literature.

\section{MEANING-CENTRISM IN INTERNATIONAL LEGAL THOUGHT AND PRACTICE}

In international legal thought and practice, any word (for example, immunity, aggression, reparation, torture, and so on), idiom (for example, opinio juris, jus cogens, force majeure, and so on), aphorism ("the parties aim to reach global peaking of greenhouse gas emissions as soon as possible," "every internationally wrongful act of a State entails the international responsibility of that State," and so on), or text (Article 53 of the Vienna Convention on the Law of Treaties, Article 38 of the Statute of the International Court of Justice, and so on) always stands for a thing, an idea, a norm, a practice, a behavior, an institution, a discourse, and so on. In that sense, the words, idioms, aphorisms, and texts of international law-what are called here the forms of the international legal discourse ${ }^{2}$ - perform a signifying function whereby they represent

1 On the idea of logocentrism, see Jacques Derrida, De la Grammatologie (Editions de Minuit 1967), 13, 21-23 (hereafter Derrida, Grammatologie); Jacques Derrida, L'Ecriture et la différence (Editions du Seuil 1967) 23 (hereafter Derrida, Ecriture). Such pattern has also been referred to as the expression of a metaphysics of presence as signs are always calling on a pre-existing meaning which they make permanently present. See Derrida, Grammatologie (n 1) 103; Jacques Derrida, Marges de la Philosophie (Editions de Minuit 1972) 187-188 (hereafter Derrida, Marges). Such logocentrism of Western thought has also been captured through the idea of the eternal journey of the sign as a representative of what it is supposed to represent. See Catherine Malabou and Jacques Derrida, La Contre-Allée (La Quinzaine Littéraire 1999) 44-45 (hereafter Malabou and Derrida, Contre-Allée).

2 Forms should not be reduced to textual inscriptions. As far as legal forms are concerned, images, symbols, gestures, paintings, ceremonies, rituals, stained glass windows, and so on are also forms which defer meaning. Forms are also in the oral language. Yet, the following chapters primarily engage with those international forms that consist of textual inscriptions. On non-textual inscriptions, see Jacques Derrida, Papier Machine (Galilée 2001) 384 (hereafter Derrida, Papier Machine). On the idea that language, even oral language, is already a type of writing, see Malabou and Derrida, Contre-Allée (n 1) 73-75. See also the remarks of Peter Goodrich, 'Europe in America: Grammatology, Legal Studies, and the Politics of Transmission' (2001) 101 Columbia 
a thing, an idea, a norm, a practice, a behavior, an institution, a discourse, and so on.

To appreciate how meaning-centrism works in international legal thought and practice, it matters to highlight that the signifying function bestowed upon the forms of the international legal discourse is only possible to the extent that such words, idioms, aphorisms, and texts of international law are distinct from the meaning they refer to, that is, from the thing, the idea, the norm, the practice, the behavior, the institution, the discourse, and so on that they represent. In fact, meaning can only be represented, carried, and delivered by the forms of the international legal discourse if it is strictly distinct from such forms. It could even be said that the distinction between meaning and form is a condition of the discourse on international law. It is only as long as the forms of the international legal discourse and the pre-existing meaning they carry and deliver are distinguished that it is possible to excavate an alleged pre-existing meaning and thus to carry out an interpretation of the forms of the international legal discourse. From this mainstream perspective, meaning is thus external to international law's words, idioms, aphorisms, and texts. ${ }^{3}$

The forms of the international legal discourse are not only distinct from (and external to) the meaning they carry and deliver. They are also secondary thereto and derived therefrom. ${ }^{4}$ In fact, according to such dominant meaning-centrism, there would be no forms in the international legal discourse if there were no preexisting meaning to carry and deliver and from which forms could be derived. This is why pre-existing meaning comes to be held, according to such dominant approach, as the cause and origin of the forms of

Law Review 2033, 2069-2084 (hereafter Goodrich, 'Europe in America'). For a similar choice to limit one's inquiry about forms to textual inscriptions, see Ntina Tzouvala, Capitalism as Civilisation: A History of International Law (CUP 2020) 18-19 (hereafter Tzouvala, Capitalism).

3 It is no coincidence that distinguishing the forms of the international legal discourse from the meaning they refer to and represent is probably one of the greatest achievements of modern legal thought as it consolidated itself in the 19th and 20th centuries. On the modern modes of representation, see gen. Timothy Mitchell, Questions of Modernity (University of Minnesota Press 2000) 17-18 (hereafter Mitchell, Modernity). See gen. Michel Foucault, Les mots et les choses (Gallimard 1966) 58, 70-72 (hereafter Foucault, Mots); Derrida, Grammatologie (n 1) 50; Bruno Latour, Nous n'avons jamais été modernes. Essai d'anthropologie symétrique (La Découverte 1997) 24 (hereafter Latour, Jamais été modernes); Emmanuel Levinas, Altérité et transcendence (Fata Morgana 1995) 17.

4 On the idea of derivation of writing in Western thought, see Malabou and Derrida, Contre-Allée (n 1) 44-45. 
the international legal discourse, such forms being always at the service of that pre-existing meaning. ${ }^{5}$

An important caveat is warranted at this stage. That the forms of the international legal discourse are thought as secondary to meaning does not entail that they have not required attention. Actually, it is to uphold the transcendence of forms and the meaning they deliver, and thus to facilitate the excavation of such pre-existing meaning from the forms of the international legal discourse, that modern international legal thought and practice have shown unprecedented care for identifying, inventorying, distinguishing, mapping, deciphering, tracing, organizing, and breaking down international law's forms. ${ }^{6}$ In that regard, it is no surprise that some of the most refined and revered scholarly works on international law pertain to the forms of the international legal discourse and that the judgments of international courts and tribunals that are deemed canonical and referenced the most are often those judgments that raise questions of forms. It is for the same reason that legal education in international law is primarily focused on mastering the forms of the international legal discourse. ${ }^{7}$

Another aspect of the dominant meaning-centrism of international legal thought and practice must be elucidated. In the meaning-centric way of thinking presented here, it is usually expected that the meaning that the forms of the international legal discourse carry and deliver is determined through difference between the form concerned and other forms in the international legal discourse. In other words, the pre-existing meaning carried and delivered by the forms of the international legal discourse is supposedly retrieved through a system of differences ${ }^{8}$ between forms themselves. It is thus by virtue of the differences between forms that the specific meaning carried and delivered by a form of the international legal discourse can be determined. For instance,

\footnotetext{
5 On the traditional idea that the form is treated as weightless and inconsequential and what matters is the substantive meaning, see Pierre Schlag, "Le Hors de Texte, C'est Moi". The Politics of Form and the Domestication of Deconstruction' (1990) 11 Cardozo Law Review 1631, 1633 (hereafter Schlag, 'The Politics of Form'). See also Vincent Forray and Sébastien Pimont, Décrire le droit ... et le transformer. Essai sur la décriture du droit (Dalloz 2017) 104 (hereafter Forray and Pimont, Décrire le droit).

6 On the idea that the disintegration of the sign is a modern achievement, see Roland Barthes, Le Bruissement de la langue: Essais critiques IV (Seuil 1984) 187 (hereafter Barthes, Essais critiques IV).

I have myself succumbed to such meaning-centric obsession in my past work, which I have long moved away from. See Jean d'Aspremont, Formalism and the Sources of International Law (OUP 2011) (hereafter, d'Aspremont, Formalism).

8 On the idea of system of differences, see Derrida, Ecriture (n 1) 426. See also the remarks of Jonathan Culler, Structuralist Poetics: Structuralism, Linguistics, and the Study of Literature (2nd edn, Routledge 2002) 5-6.
} 
custom means what it means because, as a form, it is distinct from the treaty; the doctrine of sources refers to what it refers to because, as a form, it is not the doctrine of interpretation; an armed attack represents what it represents because, as a form, it is different from the use of force; compensation entails what it entails in terms of reparation because, as a form, it cannot be conflated with satisfaction, and so on. From this dominant perspective, the differences between international law's words, idioms, aphorisms, and texts constitute what allows the allocation of a pre-existing meaning to each and every form of the international legal discourse. ${ }^{9}$

It must be acknowledged that, albeit dominant and generally unquestioned in international legal thought and practice, meaning-centrism as well as the reliance on the differences between forms to determine meaning have come under extensive scrutiny over the past decades, especially following what has been called the "linguistic turn" in international legal thought. ${ }^{10}$

The "linguistic turn" is a common shorthand that refers to a series of attitudes that include the questioning of the stability of the text, ${ }^{11}$ the playing down of authorship of law, ${ }^{12}$ the demonstration that language is a huge site of power, ${ }^{13}$ the necessity to un-trivialize legal forms, ${ }^{14}$ and so on.

In particular, the very possibility of extracting a fixed meaning from the forms of the international legal discourse has been severely challenged by some international legal scholars who, mobilizing tools from structuralism ${ }^{15}$

9 The determination of meaning through the differences between forms has been theorized in traditional structuralist linguistics, which has shown the extent to which the identity of the sign is relational and differential and can only be determined through differences with other signs. See gen. Ferdinand de Saussure, Course in General Linguistics (Charles Bally and Albert Sechehaye eds, Open Court 1986). On this aspect of the work of Saussure, see the remarks of Derrida, Ecriture (n 1) 427.

10 For some general observations on the "linguistic turn" in international legal thought, see Ingo Venzke, 'Contemporary Theories and International Lawmaking' in Catherine Brölmann and Yannick Radi (eds), Research Handbook on the Theory and Practice of International Lawmaking (Edward Elgar Publishing 2016) 66-84.

11 Peter Goodrich and others, 'Introduction: A Philosophy of Legal Enigmas' in Peter Goodrich and others (eds), Derrida and Legal Philosophy (Palgrave MacMillan 2008) 2 (hereafter Goodrich and others, 'Introduction').

12 Ibid.

13 The expression is from Goodrich, 'Europe in America' (n 2) 2043.

14 The expression is from Schlag, 'The Politics of Form' (n 5) 1633.

15 On the structuralist foundations of Martti Koskenniemi's account of international legal argumentation, see Akbar Rasulov, 'From Apology to Utopia and the Inner Life of International Law' (2016) 29 Leiden Journal of International Law 641 (hereafter Rasulov, 'Inner Life'); Sahib Singh, 'International Legal Positivism and New Approaches to International Law' in Jörg Kammerhofer and Jean d'Aspremont (eds), International Legal Positivism in a Postmodern World (CUP 2014) 291-316; Justin Desautels-Stein, 'International Legal Structuralism: A Primer' 
and popularizing findings already made in the $1970 \mathrm{~s}^{16}$ and early $1980 \mathrm{~s}^{17}$ in literary and linguistic studies, have shed light on the constant mediation between the world that is perceived (concreteness) and the world that is wanted (normativity) in the process of delivery of meaning by forms. ${ }^{18}$ Such works were later continued and supplemented by an examination of the structural biases, institutional strategies, and special ethos that inform the delivery of meaning by the forms of the international legal discourse. ${ }^{19}$ Building on earlier works on the self-explanatory character of legal forms and their inventing and organizing of their own formation and functioning, ${ }^{20}$ the international legal literature has also turned its attention to the self-referential dialectics at work in forms' system of differences and the material conditions of their productions. ${ }^{21}$

(2016) 8 International Theory 201 (hereafter Desautels-Stein, 'International Legal Structuralism'). Emmanuelle Jouannet comes with a similar but more nuanced account. See Emmanuelle Jouannet, 'A Critical Introduction' in Martti Koskenniemi (ed), The Politics of International Law (Hart Publishing 2011) 2, 7-12.

16 George Steiner, After Babel: Aspects of Language and Translation (OUP 1975).

17 Robert Cover, 'The Supreme Court, 1982 Term - Foreword: Nomos and Narrative' (1983) 97 Harvard Law Review 4, 9.

18 David Kennedy, International Legal Structures (Nomos 1987); Martti Koskenniemi, From Apology to Utopia (CUP 2005) (hereafter Koskenniemi, From Apology to Utopia); Martti Koskenniemi, 'The Fate of International Law: Between Technique and Politics' (2007) 70 Modern Law Review 1.

19 Martti Koskenniemi, 'The Politics of International Law - 20 Years Later' (2009) 20 European Journal of International Law 7-9 (hereafter Koskenniemi, 'The Politics'); David Kennedy, A World of Struggle: How Power, Law, and Expertise Shape Global Political Economy (Princeton University Press 2016).

20 See Pierre Schlag, 'Normativity and the Politics of Form' (1991) 139 University of Pennsylvania Law Review 801; Pierre Schlag, 'The Empty Circles of Liberal Justification' (1997) 96 Michigan Law Review 1. See also Pierre Bourdieu, 'The Force of Law: Toward a Sociology of the Juridical Field' (1987) 38 Hastings Law Journal 805,849 . This is what has sometimes been called self-transcendence ('auto-transcendence'). See François Ost, Du Sinaï au Champ-de-Mars: L'autre et le même au fondement du droit (Lessius 1999) 20ff. See gen. Niklas Luhmann, Social Systems (John Bednarz and Dirk Baecker trs, Stanford University Press 1995).

21 See Jean d'Aspremont, International Law as a Belief System (CUP 2017) (hereafter d'Aspremont, Belief System). See also Jean d'Aspremont, 'Three International Lawyers in a Hall of Mirrors' (2019) 32 Leiden Journal of International Law 367. 
Mention must similarly be made of these abounding works that have compellingly exposed the ideological, ${ }^{22}$ neo-colonizing, ${ }^{23}$ and masculine ${ }^{24}$ dimensions of the world-making performances of the forms of the international legal discourse and of their system of differences. ${ }^{25}$

22 Tzouvala, Capitalism (n 2); China Miéville, Between Equal Rights: A Marxist Theory of International Law (Haymarket Books 2006) (hereafter Miéville, Between Equal Rights); Liliana Obregon, 'Empire, Racial Capitalism and International Law: The Case of Manumitted Haiti and the Recognition Debt' (2018) 31 Leiden Journal of International Law 597; Rose Parfitt, The Process of International Legal Reproduction: Inequality, Historiography, Resistance (CUP 2019) (hereafter Parfitt, International Legal Reproduction). For some observations on ideology critique in international law, see Walter Rech, 'Ideology' in Jean d'Aspremont and Sahib Singh (eds), Concepts for International Law: Contributions to Disciplinary Thought (Edward Elgar Publishing 2019).

${ }^{23}$ Nathaniel Berman, 'In the Wake of Empire' (1999) 14 American University International Law Review 1515; Makau Mutua, 'What is TWAIL?' (2000) 94 American Society of International Law Proceedings 31; Makau Mutua, 'Savages, Victims and Saviors: The Metaphor of Human Rights' (2001) 42 Harvard International Law Journal 201; Sundya Pahuja, 'The Postcoloniality of International Law' (2005) 46 Harvard International Law Journal 459; Antony Anghie, 'The Evolution of International Law: Colonial and Postcolonial Realities' (2006) 27 Third World Quarterly 740; Buhpinder Chimni, 'Third World Approaches to International Law: A Manifesto' (2006) 8 International Community Law Review 18; Sundya Pahuja, Decolonising International Law: Development, Economic Growth and the Politics of Universality (CUP 2011); Antony Anghie, Imperialism, Sovereignty and the Making of International Law (CUP 2012). On the narratival structure of the contemporary discourse on imperialism in international law, see Akbar Rasulov, 'Imperialism' in Jean d'Aspremont and Sahib Singh (eds), Concepts for International Law: Contributions to Disciplinary Thought (Edward Elgar Publishing 2019) 422.

24 Hilary Charlesworth, Christine Chinkin and Shelly Wright, 'Feminist Approaches to International Law' (1991) 85 American Journal of International Law 613; Karen Knop, 'Borders of the Imagination: The State in Feminist International Law' (1994) 88 Proceedings of the ASIL Annual Meeting 14; Hilary Charlesworth, 'The Sex of the State in International Law' in Ngaire Naffine and Rosemary Owens (eds), Sexing the Subject of Law (LBC Information Services 1997); Hilary Charlesworth and Christine Chinkin, The Boundaries of International Law: A Feminist Analysis (Manchester University Press 2000); Hilary Charlesworth, 'Feminist Ambivalence about International Law' (2005) 11 International Legal Theory 1; Dianne Otto, 'Resisting the Heteronormative Imaginary of the Nation-state: Rethinking Kinship and Border Protection' in Dianne Otto (ed), Queering International Law: Possibilities, Alliances, Complicities, Risks (Routledge 2018); Hilary Charlesworth, 'Prefiguring Feminist Judgment in International Law' in Loveday Hodson and Troy Lavers (eds), Feminist Judgments in International Law (Hart Publishing 2019).

25 Koskenniemi, 'The Politics' (n 19) 7-19; Sundhya Pahuja, 'Decolonization and the Eventness of International Law' in Fleur Johns, Richard Joyce and Sundhya Pahuja (eds), Events: The Force of International Law (Routledge 2011); Ingo Venzke, How Interpretation Makes International Law: On Semantic Change and Normative 
There is little doubt that the abovementioned critical evaluations of forms' deeds and of the false necessities they induce, as well as the demonstration of their contingency, have fundamentally reshaped the ways in which many scholars approach the meaning allegedly carried and delivered by the forms of the international legal discourse. For instance, there is nowadays much greater sensibility of the international lawyer for the ways and strategies through which forms, and especially legal forms, govern, shape, dictate, and blur the minds, the imagination, and the world. Yet, it is submitted here that the critical engagements with the forms of the international legal discourse that have accompanied the "linguistic turn" and which have been mentioned here have continued to abide by the mainstream meaning-centrism described in this section. ${ }^{26}$ Even unfixed, hidden, strategically and ideologically defined, the meaning that accompanies the forms of the international legal discourse has remained construed as the cause and origin of those forms as well as of what such forms do. What is more, the very idea that the forms of the international legal discourse carry and deliver meaning, even if that meaning is said to be created at the moment of its delivery, has not been contested. In particular, the dualism which such critiques have relied on, be it the concreteness and the normativity, the center and the periphery, the form and the content, the male and the female, the universal and the particular, and so on, all continue to presuppose the presence of some kind of transcendental meaning anterior to the dichotomy that is being mobilized. ${ }^{27}$ Thus, the forms of the international

Twists (OUP 2012) (hereafter Venzke, On Semantic Change). On the success of the so-called constructivist approaches to world-making, see Nicholas Onuf, World of Our Making: Rules and Rules in Social Theory and International Relations (University of South Carolina Press 1989); Nicholas Onuf, 'The Constitution of International Society' (1994) 5 European Journal of International Law 1, 6; Jutta Brunnée and Stephen Toope, 'International Law and Constructivism: Elements of an International Theory of International Law' (2000) 39 Columbia Journal of Transnational Law 19; Jutta Brunnée and Stephen Toope, 'Constructivism and International Law' in Jeffrey L Dunoff and Mark A Pollack (eds) Interdisciplinary Perspectives on International Law and International Relations: The State of the Art (CUP 2012). For compilation of the concepts at work in world-making by international law, see Jean d'Aspremont and Sahib Singh (eds), Concepts for International Law: Contributions to Disciplinary Thought (Edward Elgar Publishing 2019). See also the general observations of Andrea Bianchi, International Law Theories: An Inquiry into Different Ways of Thinking (OUP 2016) 16-19.

26 It must be acknowledged that departing from meaning-centrism was not necessary for these critical works to fulfil their ambitions. For instance, one does not need to de-necessitate meaning-centrism to show the false necessities which these forms induce and rely on or to shed light on their contingency.

27 Jacques Derrida, Positions (Editions de Minuit 1972) 41 (hereafter Derrida, Positions); Maurice Merleau-Ponty, Signes (Gallimard 1960) 70-73 (hereafter Merleau-Ponty, Signes). 
legal discourse - and all of what they do horribly wrong - have continued to be discussed in relation to the meaning that they carry and deliver. This meaning-centric feature of critical scholarship has already been acknowledged and discussed in the literature. ${ }^{28}$ It is accordingly not necessary to expose it further. What matters to stress here is that the meaning-centrism dominating international legal thought and practice has never been seriously discontinued or contested. ${ }^{29}$ Whilst copiously borrowing from structuralist modes of thinking, ${ }^{30}$ the critical works that have been mentioned above have fallen short of realizing the post-structuralist ${ }^{31}$ revolution in international legal thought and practice. $^{32}$

28 See eg the remarks of Parfitt, International Legal Reproduction (n 22) 21; Tzouvala, Capitalism (n 2) 38-40; Fuad Zarbiyev, Le discours interprétatif en droit international (Bruylant 2015) 109-118 (hereafter Zarbiyev, Discours interprétatif). See also the remarks of Akbar Rasulov who argues that Martti Koskenniemi's engagement with structuralism in From Apology to Utopia (Koskenniemi, From Apology to Utopia (n 18)) is much more on the side of traditional French(-speaking) structuralism and that it is more a structuralism à la Saussure (see Rasulov, 'Inner Life' (n 15)). Cf the remarks of China Miéville on the work of Martti Koskenniemi in Miéville, Between Equal Rights (n 22) 55-56. For a similar claim about the meaning-centric use of deconstruction in US legal scholarship, see Schlag, 'The Politics of Form' (n 5) 1643-1645.

29 On how critique has remained attached to the modern distinction between the form and the world, see gen. Mitchell, Modernity (n 3) 20.

30 For a very insightful overview of the merits of structuralism for international legal thought, see Desautels-Stein, 'International Legal Structuralism' (n 15); Justin Desautels-Stein, 'Structuralist Legal Histories' (2015) 78 Law and Contemporary Problems 37. See also the remarks of David Kennedy, 'Critical Theory, Structuralism and Contemporary Legal Scholarship' (1986) 21 New England Law Review 209 (hereafter Kennedy, 'Critical Theory'); Martti Koskenniemi, 'What Is Critical Research in International Law? Celebrating Structuralism' (2016) 29 Leiden Journal of International Law 727. On the unexploited potential of structuralism in international legal thought, see the remarks by Tzouvala, Capitalism (n 2) 5-7.

31 On the various uses of structuralist semiology and the move from structuralism to post-structuralism, see Roland Barthes, L'aventure sémiologique (Seuil 1985) 9-14 (hereafter Barthes, L'aventure sémiologique). On the distinction between structuralism and post-structuralism, see Jonathan Culler, On Deconstruction: Theory and Criticism after Structuralism (Routledge 2008) 22-30 (hereafter Culler, On Deconstruction). Cf the idea of superstructuralism of Richard Harland to encapsulate the work of both structuralists and poststructuralists as well as to account for the work of those thinkers that do not really fit in either of these categories or have moved between them: see Richard Harland, Superstructuralism: The Philosophy of Structuralism and Post-Structuralism (Routledge 1987) (hereafter Harland, Superstructuralism).

32 This affirmation will certainly prove polemical. This is why it must be complemented by a few observations. The point here is certainly not that the work of post-structuralist thinkers like Derrida has been overlooked by legal scholars, let alone by international legal scholars. For instance, David Kennedy has shown serious engagement with the work of Jacques Derrida in the 1980s (see eg Kennedy, 'Critical 


\section{THE MAIN MODES OF THINKING ASSOCIATED WITH MEANING-CENTRISM}

The meaning-centrism of international legal thought, according to which meaning necessarily pre-exists forms of which it is the cause and origin, manifests itself in myriads of ways. This book zeroes in on three main expressions of meaning-centrism, which it respectively calls originist thinking, deliverability thinking, and reifying thinking. Whilst Chapter 2 below illustrates the working of these three manifestations of meaning-centrism in contemporary international legal thought and practice, it is the aim of this section to provide a few definitional observations on how originist thinking, deliverability thinking, and reifying thinking bespeak, each in their own way, the idea that meaning pre-exists the forms of the international legal discourse, and thus the centrality of meaning.

Theory' (n 30) 284-287). For his part, Martti Koskenniemi has referred to Derrida in the first footnote of From Apology to Utopia, which he however deems "less accessible" (Koskenniemi, From Apology to Utopia (n 18) 6). Yet, the point made here is more that Derrida, contrary to Foucault, has never been very explicitly relied onand "exploited," so to speak - in international legal literature. In this regard, see the remarks of Juan M Amaya-Castro and Hassan El Menyawi, 'Moving Away From Moving Away: A Conversation About Jacques Derrida and Legal Scholarship' (2005) 6 German Law Journal 101, 106-107 (hereafter Amaya-Castro and El Menyawi, 'Moving Away'). A possible explanation for this lack of explicit reliance on Derrida lies in the extent to which a great deal of post-structuralist thought has been obfuscated and hijacked by the debate on the merits of deconstruction (for some famous examples of a discussion of Derrida through the sole lens of deconstruction, see Jack M Balkin, 'Deconstructive Practice and Legal Theory' (1987) 96 Yale Law Journal 743 (hereafter Balkin, 'Deconstructive Practice'); Jack M Balkin, 'Deconstruction's Legal Career' (2005) 27 Cardozo Law Review 719. See the criticisms of Balkin's treatment of Deconstruction by Schlag, 'The Politics of Form' (n 5). On the claim that the attention in legal scholarship was deflected away from Derrida by virtue of the debate on deconstruction, see Goodrich, 'Europe in America' (n 2) 2037-2042. On the idea that Derrida's has been a fashionable label but was not really read, see Goodrich and others, 'Introduction' (n 11) 4, 7-10. On the idea that the reception of the work of Derrida and especially the main insights of Grammatology have yet to occur in legal academia, see Goodrich, 'Europe in America' (n 2) 2041-2042. See however the use of Derrida by Schlag, 'The Politics of Form' (n 5). For an account of the common themes and sensibilities shared by critical legal scholars and Derrida, see Serpil Tunç Utebay, Justice en tant que loi, justice au-delà de la loi: Hobbes, Derrida et les Critical Legal Studies (L'Harmattan 2017) 177-221 (hereafter Tunç Utebay, Justice en tant que loi). For an interesting rebuttal by Derrida himself of the uses of deconstruction in the United States, see Jacques Derrida, 'Letter to a Japanese Friend' in David Wood and Robert Bernasconi (eds), Derrida and Différance (Northwestern University Press 1988) 3 (hereafter Derrida, 'Letter to a Japanese Friend'). 


\section{$2.1 \quad$ Originist Thinking}

Originist thinking refers here to the common understanding of forms as necessarily having an origin, an author, and a context of making. Said differently, originist thinking corresponds to the experience of a necessity to search for an origin of the forms of the international legal discourse. From such perspective, international law's words, idioms, aphorisms, and texts are supposed to always have an origin, a source, an author, and a context that can, if needed, be unearthed, recorded, revived, or simply studied. ${ }^{33}$ As is reflected in the amount of scholarly efforts spent on "finding" or "retrieving" the source, the authors, and the context of the forms of the international legal discourse, ${ }^{34}$ it is fair to say that originist thinking is deeply entrenched in international legal thought and practice.

Originist thinking, as is understood here, is not only the expression of the appetite for genealogy of modern legal thought ${ }^{35}$ but is more fundamentally a reflection of the meaning-centrism described above. ${ }^{36}$ Indeed, as long as the forms of the international legal discourse are thought as having been caused by the pre-existing meaning that they are meant to carry and deliver, international legal thought and practice cannot turn a blind eye to the origin, source, actors, and context at work in the loading of that meaning onto the forms of the international legal discourse carrying and delivering them. ${ }^{37}$ Such origin, and thus the source, the author, and the context of forms, is experienced as a necessity, for they are supposed to subsequently direct the functioning of the forms concerned and constitute their centre. ${ }^{38}$

33 Unearthing the sources and the authors of the forms of the international legal discourse has been the object of some of my earlier inquiries. See d'Aspremont, Belief System (n 21). See also d'Aspremont, Formalism (n 7).

34 On the complicity of source-discourse with originist thinking, see Derrida, Marges (n 1) 13; Barthes, Essais critiques IV (n 6) 63-69.

35 On the idea that the question of production of human artefacts and human discourses is very modern, see Michel de Certeau, L'écriture de l'histoire (Gallimard 1975) 27-28. See also Barthes, Essais critiques IV (n 6) 63-69.

36 See Chapter 1, Section 1.

37 For a traditional affirmation of such meaning-centric understanding of the context, see Quentin Skinner, The Foundations of Modern Political Thought, vol 1 (CUP 1998) ix, xiii.

38 On this traditional mode of thinking, see Derrida, Ecriture (n 1) 409-410; Jacques Derrida, The Beast and the Sovereign, vol 1 (University of Chicago Press 2011) 17 (hereafter Derrida, The Beast and the Sovereign, vol 1); Barthes, Essais critiques IV (n 6) $75,139$. 


\subsection{Deliverability Thinking}

International legal thought and practice are also dominated by a meaning-centric leaning for what is called here deliverability thinking, ${ }^{39}$ whereby formswhether they are thought of as carrying pre-existing meaning loaded onto them or not - come to the point when they deliver meaning. ${ }^{40}$ Deliverability thinking corresponds to the experience of a necessity to search for a content for the forms concerned. ${ }^{41}$ The strong version of such deliverability thinking posits that the meaning loaded onto the forms of the international legal discourse is never found at the surface of the form and ready to be delivered but requires a careful process of extraction, the latter being commonly referred to as "interpretation." According to this strong version of deliverability thinking, interpretation refers to the process of extraction of the pre-existing meaning that has allegedly been loaded onto the forms of the international legal discourse and which the latter are supposed to carry and deliver. Although this strong version of deliverability thinking may not necessarily correspond to an actual belief and often amounts to a casual and inarticulate disciplinary narrative, it has been extensively debunked in international legal literature for several decades. Indeed, it is common to reduce the extraction of the meaning that is loaded onto international legal thought to a theatrical performance ${ }^{42}$ and to claim that the interpretation of forms is always performative in that it constitutes the meaning thereof. ${ }^{43}$ Likewise, approaches that emphasize the reader as well as the readership community ${ }^{44}$ have gained popularity, thereby further discrediting the strong version of deliverability thinking. ${ }^{45}$

39 I have been tempted to call it "inventory thinking." On the idea of interpretation and the action of inventorying, see Merleau-Ponty, Signes (n 27) 260.

40 On the idea that law is not only a form of inscription but also a system of delivery, see Goodrich, 'Europe in America' (n 2) 2066.

41 Deliverability thinking often comes with a presumption of inconsequentiality and weightlessness of forms in the process of transmission of meaning. See Schlag, 'The Politics of Form' (n 5) 1633.

42 On the metaphor of the theater, see Stephen Humphreys, Theatre of the Rule of Law: Transnational Legal Intervention in Theory and Practice (CUP 2010).

43 See eg Venzke, On Semantic Change (n 25).

44 For a classic, see also Stanley Fish, Is There a Text in This Class? The Authority of Interpretive Communities (Harvard University Press 1980); Stanley Fish, 'Fish v. Fiss' (1984) 36 Stanford Law Review 1325.

45 See Andrea Bianchi, 'The Game of Interpretation in International Law: The Players, the Cards, and Why the Game is Worth the Candle' in Andrea Bianchi, Daniel Peat and Matthew Windsor (eds), Interpretation in International Law (OUP 2015); Andrea Bianchi, 'Textual Interpretation and (International) Law Reading: The Myth of (in) Determinacy and the Genealogy of Meaning' in Pieter Bekker (ed), Making Transnational Law Work in the Global Economy - Essays in Honour 
Importantly, even if deliverability thinking has not survived in its strong version, the presupposition that the forms of the international legal discourse deliver meaning on which it is predicated has endured in international legal thought and practice. Indeed, notwithstanding the-nowadays rather mainstream - claims about indeterminacy, the performative effects of interpretation, and the primacy of the reader, the very postulation that the forms of the international legal discourse deliver meaning continues to be upheld across the board, for the form is still held as delivering meaning at one point or another. In that sense, international legal thought and practice, notwithstanding the common acceptance that meaning is created in the process of extraction, continues to be dominated by deliverability thinking by virtue of which the forms of the international legal discourse supposedly deliver meaning. Even the most critical takes on delivery thinking continue to be predicated on the idea that the forms of the international legal discourse simply mean. ${ }^{46}$

\subsection{Reifying Thinking}

Meaning-centrism similarly manifests itself in the presupposition that the pre-existing meaning which forms carry and deliver is anchored in a certain reality. This is what is called here reifying thinking. By virtue of reifying thinking, the thing, the idea, the norm, the practice, the behavior, the institution, the discourse, and so on which the forms of the international legal discourse represent are supposedly real. Said differently, reifying thinking entails that the forms of the international legal discourse are responding to certain facts. Reifying thinking thus corresponds to the experience of a necessity to search for a reality of forms. It is noteworthy that such reifying thinking, in a strong variant, sometimes goes as far as considering that forms themselves constitute a thing: words, idioms, aphorisms, and texts are often deemed to have a material actuality and to belong to the order of things. According to such strong variant, reifying thinking entails that in international legal thought and practice, forms are not only responses to facts and grounded in facts but they are also artefacts (about the facts they respond to and are grounded in).

of Detlev Vagts (CUP 2010) 35. This used to be my position too. See Jean d'Aspremont, Epistemic Forces in International Law (Edward Elgar 2016); Jean d'Aspremont, 'The Multidimensional Process of Interpretation: Content-Determination and Law-Ascertainment Distinguished' in Andrea Bianchi, Daniel Peat and Matthew Windsor (eds), Interpretation in International Law (OUP 2015) (hereafter d'Aspremont, 'The Multidimensional Process').

46 On the dominance of meaning as vouloir-dire in contemporary thought in general, see Derrida, Positions (n 27) 66-67. 


\section{MOVING AWAY FROM MEANING-CENTRISM: THE SOVEREIGNTY OF FORMS}

This book questions the meaning-centrism of international legal thought and practice, and the various manifestations thereof as they have been introduced in the previous section. This book demonstrates that the forms of the international legal discourse do not carry and deliver any pre-existing meaning and that meaning cannot be the cause and origin of such forms. This book particularly argues that the words, idioms, aphorisms, and texts of international law do not carry and deliver any pre-existing meaning but, instead, constantly postpone meaning, thereby condemning meaning to be permanently absent from forms. Indeed, according to the argument made here, when asked to signify a thing, an idea, a norm, a practice, a behavior, an institution, a discourse, and so on, the forms of the international legal discourse constantly pass on the job of signification to other forms. When these other forms to which signification is passed are, in turn, asked to signify, they will similarly point away to yet other forms. In other words, when asked to signify a thing, an idea, a norm, a practice, a behavior, an institution, a discourse, and so on, the forms of the international legal discourse permanently defer meaning to other forms without such deferral process ever being completed and meaning ever being pinned down. The signification of words, idioms, aphorisms, and texts of international law never closes or ends, remaining indefinitely caught in a chain of supplements. ${ }^{47}$ As a result of it being constantly passed on to another legal form, meaning is permanently deferred ${ }^{48}$ and condemned to be nomadic. ${ }^{49}$ Being perpetually deferred, meaning is eternally absent and nowhere to be found in the forms of the international legal discourse of which it cannot be the cause or the origin. ${ }^{50}$ By perpetually deferring meaning and ensuring its absence, the forms of the international legal discourse, as this book claims, can sovereignly reign over international legal thought and practice..$^{51}$

Before developing this claim further in the ensuing chapters, it must be emphasized that deferring meaning, as the forms of the international legal dis-

47 Derrida, Positions (n 27) 54.

48 In the same vein, see Goodrich, 'Europe in America' (n 2) 2059.

49 The expression is from Pierre Legrand, "Il n'y a pas de hors-texte": Intimations of Jacques Derrida as Comparatist-at-Law' in Peter Goodrich and others (eds), Derrida and Legal Philosophy (Palgrave MacMillan 2008) 131 (hereafter Legrand, 'Il n'y a pas de hors-texte').

50 In the same vein, Zarbiyev, Discours interprétatif (n 28) 37-45. See also Goodrich, 'Europe in America' (n 2) 2062.

51 Cf the idea that sign works 'despotically' by Harland, Superstructuralism (n 31) 124. 
course do, is no deficiency that calls for fixing or mitigation. It is argued here that, quite the opposite, the deferral of meaning by forms is the very condition of forms. In that sense, the forms of the international legal discourse are bound to defer meaning for them to function as forms. Actually, in the presence of meaning, the forms of the international legal discourse would cease to be forms: they would be made redundant by the arrival of meaning. ${ }^{52}$

Two aspects of the sovereignty of forms, as is understood here, must now draw the attention. First, it must be shown that the deferral of meaning by the forms of the international legal discourse is not confined to a specific social or disciplinary space and that such deferral of meaning cannot be approached as a phenomenon, let alone a legal phenomenon (3.1). Second, and most importantly, the way in which the deferral of meaning by the forms of the international legal discourse plays out must be further elucidated. On that occasion, it will be demonstrated that the deferral of meaning is possible by virtue of each form's self-difference (3.2).

\subsection{A Sovereignty Without Borders}

Although the deferral of meaning by the forms of the international legal discourse is no material or natural phenomenon, let alone a phenomenon that can be ascribed to a specific location, an important remark is warranted as to the impossibility of assigning the deferral of meaning by the forms of the international legal discourse to a specific social or disciplinary space.

It must be acknowledged that the deferral of meaning by the forms of the international legal discourse is most visible between the forms of the international legal discourse themselves. For sure, for the international lawyer, the chain of supplements through which meaning is perpetually moving is most visibly composed of forms which she is trained to invoke and explicitly respond to. For instance, and without the following corresponding to any unique or fixed deferral process, custom possibly refers to practice, practice possibly refers to states, states possibly refer to state officials, and so on. To take but another example, the idiom of wrongful act possibly refers to breach, breach possibly refers to bindingness, bindingness possibly refers to sources, sources possibly refer to Article 38 , and so on. Yet, it is of the utmost importance to stress that the deferral of meaning by the forms of the international legal discourse is not confined to any legal space. Actually, the deferral of meaning knows no border, let alone any social or disciplinary border, for any bordering of the deferral of meaning is itself caught in the deferral of meaning.

52 See the analogy with theology and philosophy made by Peter Salmon, An Event, Perhaps (Verso 2020) 15 (hereafter Salmon, An Event, Perhaps). 
In that sense, the deferral of meaning by the forms of the international legal discourse is out of any social or disciplinary space. To return to the abovementioned example, wrongful act possibly refers to the idea of wrong too; wrong possibly refers to the idea of inadmissible behavior; which in turns possibly refers to the idea of good; which then possibly mobilizes certain strategies of moral universalization; which possibly raises a question of hegemony, and so on. Likewise, custom possibly refers to social acceptability, which possibly refers to the idea of society or community, which possibly refers to a certain idea of the social contract, which in turn possibly makes modern mode of thinking surface, and all that comes with it.

That the deferral of meaning by the forms of the international legal discourse is out of space and knows no social or disciplinary border bears an important consequence that ought to be mentioned here. The sovereignty of forms in international law is not reserved to those forms which the international lawyer is specifically trained to invoke and respond to but is a privilege of all forms. Said differently, the deferral of meaning by the forms of the international legal discourse is neither in nor out of the "legal." 53 Actually, the very distinction between the "legal" and the "non-legal"- just like any social or disciplinary ordering $^{54}$ - is itself a form caught in a chain of supplements and whose meaning is perpetually deferred. ${ }^{55}$ Claiming otherwise and, thus, reducing the deferral of meaning by the forms of the international legal discourse to a "legal" phenomenon taking place in a specific social or disciplinary space would presuppose a transcendental legal phenomenon, thereby perpetuating, rather than debunking, the dominant meaning-centrism of international legal thought and practice. The deferral of meaning by the forms of the international

53 In that regard, Pierre Legrand has claimed that the different discourses that are traditionally be said to be outside the law are not existing outside of it but are of it. See Pierre Legrand, 'Foreign Law: Understanding Understanding' (2011) 6 Journal of Comparative Law 67, 80-81 (hereafter Legrand, 'Understanding Understanding').

54 On the idea that distinctions, and especially disciplinary distinctions, are powerful modes of ordering, see Roland Barthes, Leçon (Seuil 1978) 12; Latour, Jamais été modernes (n 3) 68-69; Foucault, Mots (n 3) 68-69. For a specific discussion of such disciplinary ordering in relation to international law, see Jean d'Aspremont, 'International Law, Theory, and History: Ordering through Distinctions' in Jean d'Aspremont (ed), The History and Theory of International Law, vol 1 (Edward Elgar Publishing 2020) x.

55 For some remarks on the disciplinary pedigrees of concepts and forms, see Vidya Kumar, 'Revolutionaries' in Jean d'Aspremont and Sahib Singh (eds), Concepts for International Law. Contributions to Disciplinary Thought (Edward Elgar Publishing 2019) 773. See also Jean d'Aspremont, 'Legal Imagination and the Thinking of the Impossible', Leiden Journal of International Law (forthcoming). 
legal discourse reminds us that the international legal discourse does not exist in isolation from other discourses. ${ }^{56}$

\subsection{Sovereign Forms and Self-Difference}

The claim that forms postpone meaning by perpetually deferring the latter and thereby leaving the process of signification eternally unachieved is no novel affirmation. It corresponds to a finding that has been compellingly theorized in post-structuralist philosophy and literary theory and which ought not to be recalled here. ${ }^{57}$ Yet, what post-structuralist philosophy and literary theory can teach the international lawyer is that the abovementioned permanent deferral of meaning and thus the latter's perpetual absence entail neither the emptiness of forms nor a conflation between them. Indeed, it is possible for the forms of the international legal discourse to have an identity of their own short of any ingrained or assigned pre-existing meaning. In other words, the forms of the international legal discourse have a meaning-less identity, that is, an identity that cannot be reduced to any fixed or inherent meaning. The identity of forms, post-structuralist philosophy and literary theory, lies in the forms' self-difference. ${ }^{58}$

56 Pierre Legrand, 'Siting Foreign Law: How Derrida Can Help' (2011) 21 Duke Journal of Comparative and International Law 595, 609 (Legrand, 'Siting Foreign Law').

57 Derrida, Grammatologie (n 1) 11-126; Derrida, Marges (n 1) 1-29; Derrida, Ecriture (n 1) 411. On this aspect of the work of Derrida, see the remarks of Salmon, An Event, Perhaps (n 52) 12. See also Geoffrey Bennington, Jacques Derrida (Seuil 1991) 56 (hereafter Bennington, Jacques Derrida). Cf Barthes, Essais critiques IV (n 6); Roland Barthes, S/Z (Seuil 1970) 9-11 (hereafter Barthes, $S / Z$ ). On the idea that Derrida's Grammatology is predicated upon a Talmudic conception of an infinite text and belonged to a tradition of interpretation rooted in the pre-Christian world, see Goodrich, 'Europe in America' (n 2) 2033-2084. See also Jürgen Habermas, The Philosophical Discourse of Modernity: Twelve Lectures (Frederik Lawrence tr, Polity Press 1987) 165. Cf Gillian Rose, The Dialectic of Nihilism: Post-Structuralism and Law (Basil Blackwell 1984) 133-135. For a rejection by Derrida of any influence of the Talmudic tradition of commentary, see Derrida, Papier Machine (n 2) 373. For an earlier, albeit still meaning-centric, contestation of the idea that language is the instrument of a pre-existing thought, see Edward Sapir, Language: An Introduction to the Study of Speech (Ishi Press 2014) 14-17 (who claims that language performs a pre-rational function and that the thought and the words grow together in a dialectic manner).

58 "Self-difference" is one of the ways in which Derrida's idea of différance has been translated in English. Simon Glendinning, Derrida. A Very Short Introduction (OUP 2011) 62. Cf the translation of différance as spacing by Culler, On Deconstruction (n 31) 97. On the concept of différance, see Derrida, Marges (n 1) 1-29; Derrida, Positions (n 27) 17,37-41. See the application of the concept of différance by Derrida, The Beast 
This possibility of upholding the identity of forms through self-difference is critical for the argument made here as it demonstrates that moving away from the meaning-centrism that dominates international legal thought and practice is not exclusive of each and every form of the international legal discourse having a distinct identity. In fact, although meaning is perpetually deferred by the forms of the international legal discourse, invalidity is not wrongfulness, general principles of law are not customary law, an armed attack is not a use of force, an injured state is not a non-injured state, responsibility is not liability, jus cogens is not erga omnes, and so on. Notwithstanding the perpetual deferral of meaning, the forms of the international legal discourse have their own distinct identity and can neither be deemed empty nor conflated with one another.

To appreciate how each and every form of the international legal discourse has an identity of its own despite it carrying and delivering no pre-existing meaning, two observations are warranted about what the identity of forms cannot possibly be. First, it should be repeated that the distinct identity of each and every form of the international legal discourse is not any kind of inherent meaning or meaning in disguise, for that would contradict the constant deferral of meaning and re-introduce the very meaning-centrism with which this book takes issue. Second, and more fundamentally, it must be emphasized that the distinct identity of the forms of the international legal discourse is not simply and mechanically constituted by the relationships of difference with other forms, for this would, once again, re-introduce a presupposition of a transcendental pre-existing meaning typical of meaning-centrism. ${ }^{59}$

If not from any inherent meaning, from some meaning in disguise, or from relationships of difference with other forms, what is it that makes a form what it is and not another form? In other words, what is the self-difference of forms if not some kind of inherent meaning, some meaning in disguise or the result of a system of differences à la Saussure? It is argued here that the difference with other forms is not outside the form concerned - that is, in its relationship of difference with other forms - but within each and every form. More specifically, each and every form differentiates itself from others by virtue of the

and the Sovereign, vol 1 (n 38). See the comments of Bennington, Jacques Derrida (n 57) 70-82. See also the comments of Salmon, An Event, Perhaps (n 52) 107. See also Tunç Utebay, Justice en tant que loi (n 32) 79-81. On the kinship between Derrida's différance and the work of Heidegger, see Walter A Brogan, 'The Original Difference' in David Wood and Robert Bernasconi (eds), Derrida and Différance (Northwestern University Press 1988) 31.

59 This is the presupposition of what has been called the transcendental signified. See Derrida, Grammatologie (n 1) 24, 69-70; see also Derrida, Positions (n 27) 30. See also Merleau-Ponty, Signes (n 27) 70-73. 
otherness within itself. To take but a few examples from the international legal discourse, it is by virtue of such self-difference that invalidity is not wrongfulness, general principles of law are not customary law, an armed attack is not a use of force, an injured state is not a non-injured state, responsibility is not liability, jus cogens is not erga omnes, and so on. Inhabited by what it is not, each and every form of the international legal discourse has an identity of its own. ${ }^{60}$

The difference within the selfsame which informs the work of self-difference is sometimes captured through the notion of trace which is said to haunt the form. ${ }^{61}$ The trace is "the event of the other-in-the-law." ${ }^{62}$ It indicates the vanishing presence of other forms of which it is a vestige. ${ }^{63}$ The trace has already disappeared when it is noticed. It is thus absent too. ${ }^{64}$ In that sense, the trace is a ghost of the other. ${ }^{65}$ The trace is itself porous, always unfinished, and only traceable to other traces. ${ }^{66}$ It can accordingly never be encountered as an object or as data, ${ }^{67}$ let alone serve as a foundation ${ }^{68}$ or context ${ }^{69}$ of the form and of its self-difference. In other words, the trace is no surrogate for any pre-existing meaning, for it is always being induced and constructed in the process of

60 For some illustrations of the work of self-difference in relation to legal texts, see Forray and Pimont, Décrire le droit (n 5) 219-222.

${ }_{61}$ On the notion of trace, see gen. Derrida, Grammatologie (n 1) 86-87. See also Bennington, Jacques Derrida (n 57) 73-75; Tunç Utebay, Justice en tant que loi (n 32) 81-82. On the idea that that trace haunts the text, see Jacques Derrida, Spectres de Marx (Galilée 1993) (hereafter Derrida, Spectres de Marx); Derrida, Papier Machine (n 2) 307. On this question of spectral dimension of legal texts, see Legrand, 'Siting Foreign Law' (n 56) 607. See also Legrand, 'Understanding Understanding' (n 53) 78.

62 Legrand, 'Understanding Understanding' (n 53) 82.

63 Legrand, 'Il n'y a pas de hors-texte' (n 49) 131. See also Legrand, 'Siting Foreign Law' (n 56) 607.

64 Derrida claims that this self-difference is out of both the order of representation and the order of things and approaches "it" as neither a form nor a thing. Self-difference is out of space, temporality, causality, sensibility, as well as out of representation. See Derrida, Marges (n 1) 1-29. On the idea that the trace refers to the remnants of what is left, see Derrida, Papier Machine (n 2) 385. With a specific emphasis on legal studies, see the remarks of Legrand, 'Understanding Understanding' (n 53) 79. See also Tunç Utebay, Justice en tant que loi (n 32) 77-79.

65 On the idea of ghost, see Legrand, 'Siting Foreign Law' (n 56) 607.

66 Legrand, 'Understanding Understanding' (n 53) 79; Legrand, 'Il n'y a pas de hors-texte' (n 49) 131.

67 Legrand, 'Understanding Understanding' (n 53) 82.

68 In the same vein and in relation to legal studies, see Balkin, 'Deconstructive Practice' (n 32) 743.

69 Legrand, 'Understanding Understanding' (n 53) 79. 
deferral of meaning. ${ }^{70}$ The notion of trace-which verbalizes the work of self-difference, that is, the difference within the selfsame - is helpful to understand how self-difference allows forms to have a distinct identity short of any pre-existing meaning and of a system of differences. Indeed, each form carries the trace of what it is not, that is, the mark of other forms which it is different from. It is the trace of other forms (which is a difference within the selfsame) that confers the identity to the form. As a result of this trace of what it is not, each and every form of the international legal discourse can be said to have a divided identity, such form being always already inhabited by other forms.

That the identity of forms is a divided identity by virtue of the trace of other forms calls for yet another important remark. Such divided identity cannot be a binary identity and the trace of the other cannot be the trace of an opposite. ${ }^{71}$ For sure, a form of the international legal discourse is inhabited by the traces of other forms that seem at variance with - and which differ from - the form being inhabited. Yet, such difference ought not to be construed as an opposite, for doing so would reduce self-difference to meaning. Indeed, as long as the other that inhabits the form constitutes its opposite, there is a presupposition of a fixed meaning by virtue of which the opposition is constructed and apprehended. Said differently, construing self-difference as a binary identity, and thus understanding the trace of the other as a trace of the opposite, amounts to a meaning-centric move that empties the sovereignty of forms. The other within the selfsame is not the opposite other but only an other. ${ }^{72}$

As the foregoing should show, self-difference, difference within the selfsame, and trace, which are the notions that have been relied on here to shed light on the deferral of meaning by the forms of the international legal discourse and explain the sovereignty of forms, are themselves caught in a deferral of meaning together with the notion of deferral of meaning and that of the

70 Derrida, Positions (n 27) 39. See Zarbiyev, Discours interprétatif (n 28) 43-45. For a discussion of this idea in relation to legal studies, see Legrand, 'Understanding Understanding' (n 53) 82; Legrand, 'Siting Foreign Law' (n 56) 609.

71 Derrida himself may have proved rather ambiguous on this point. On the one hand, he claims that the work of self-identity is not binary (see Derrida, Positions (n 27) 39. See also Malabou and Derrida, Contre-Allée (n 1) 73). On the other hand, in a move that he tries to strip of its Hegelian overtones, he claims that deconstruction must reverse hierarchies. See Derrida, Positions (n 27) 56-61. On this latter aspect of Derrida, see Salmon, An Event, Perhaps (n 52) 81.

72 Reducing the divided identity of forms to a binary identity has often been witnessed in critical legal scholarship. See eg Balkin, 'Deconstructive Practice' (n 32) 754. This is yet another reason why critical legal scholarship has remained very meaning-centric. It is a question to which the following chapter returns. See Chapter 2, Sections 2.2 and 2.3. See also Chapter 4, Sections 1 and 3. 
sovereignty of forms. ${ }^{73}$ In fact, forms' identity through self-difference whose work can be captured through the trace of others is part of the very sovereignty of forms and of their perpetual deferral of meaning. ${ }^{74}$ Put simply, it could be said that self-difference, difference within the selfsame, trace, the deferral of meaning, and the sovereignty of forms simply hang together. On the one hand, identity through self-difference is the condition of possibility of the deferral of meaning, for, short of a distinct identity through self-difference, the forms of the international legal discourse could not defer meaning. On the other hand, deferral of meaning is what upholds the forms' identity, for it is the forms to which meaning is pushed back that inhabit the form concerned and provide the latter with an identity.

\section{THE SOVEREIGNTY OF FORMS AND ITS IMPLICATIONS}

From the perspective of the sovereignty of forms foregrounded here, the forms of the international legal discourse do not carry and deliver pre-existing meaning but, instead, perpetually defer meaning by virtue of their identity-constituting self-difference. Being constantly deferred, meaning is made perpetually absent and leaves the forms to sovereignly reign over international legal thought and practice.

Putting the emphasis on the sovereignty of forms bears major consequences for the three abovementioned meaning-centric modes of thinking witnessed in international legal thought and practice, namely originist thinking, deliverability thinking, and reifying thinking. ${ }^{75}$ As was already said, it is the ambition of the final chapter of this book to elaborate on some of the consequences of the sovereignty of forms for the international legal discourse as a whole. ${ }^{76}$ Yet, even at this introductory stage, mention must be made of three major implications of the sovereignty of forms. These three major implications correspond to the de-necessitating of three traditional necessitarian moves in international legal thought and practice, namely the necessity of the quest for an origin, the necessity of the quest for content, and the necessity of the quest for reality-

73 On the idea that trace and différance and all the other notions that Derrida mobilizes let themselves be replaced by one another and are replaceable in a chain of substitution, see hereafter Derrida, 'Letter to a Japanese Friend' (n 32) 4-5.

74 This is what justifies that Jacques Derrida deliberately misspelled 'différance' in French. Indeed, "différance" plays on the fact that the French word différer means both "to defer" and "to differ," the substitution of a to the e of difference referring to "differant" (deferring). See Derrida, Marges (n 1) 8-9; Derrida, Positions (n 27) 54.

75 See Chapter 1, Section 2.

76 See Chapter 4. 
which respectively are the expression of originist thinking, deliverability thinking, and reifying thinking.

\subsection{De-necessitating the Quest for Origin}

The sovereignty of forms according to which the forms of the international legal discourse have no origin, no author, no context other than forms to which meaning is deferred, and of which they bear the trace, comes to seriously question what has been called here the originist thinking that informs international legal thought and practice. This can be explained as follows. From the perspective of the sovereignty of forms, those forms - that neither carry nor deliver any pre-existing meaning - are identified through self-difference - that is, the trace of other forms within the selfsame - rather than any pre-existing meaning. ${ }^{77}$ By virtue of such divided identity, the sovereign forms of the international legal discourse already bear the trace of all the forms that preceded them. The origin, the author, and the context of forms already inhabit them. In that sense, the origin of forms is always a repetition of those forms. ${ }^{78}$ One could even say that forms always begin before they begin. ${ }^{79}$ In other words, the origin of forms always ensues from the forms themselves and thus cannot any longer be the origin of that form. ${ }^{80}$ Thus, the supposed origin of a given form of the international legal discourse is always secondary to that form, thereby making that origin an impossibility - for someone or something cannot be the origin of what it is secondary to. As a result, it is never possible to pinpoint a making-moment or a making-event independent from forms, for that making-moment or making-event is itself already in the forms and caught in the deferral of meaning.

\footnotetext{
77 Jacques Derrida, Marges de la Philosophie (Editions de Minuit 1972) 15.

78 See Vincent Descombes, Le Même et l'Autre. Quarante-cinq ans de philosophie française (Editions de Minuit 1979) 171.

79 On the idea that writing has no beginning, see Derrida, Positions (n 27) 23. See also Derrida, Spectres de Marx (n 61) 255-56.

80 See Derrida, Marges (n 1) 12-17; Derrida, Ecriture (n 1) 410; Derrida, Grammatologie (n 1) 87. On this aspect of Derrida, see the remarks of Bennington, Jacques Derrida (n 57) 4; Salmon, An Event, Perhaps (n 52) 50-51. In rejecting the common claim of an origin of the sign as being outside the sign, Derrida transposed his criticism of Husserl's phenomenology as resting on preconceptual originary moment to his critique of structuralism. See Derrida's criticisms of Husserl in Derrida, Marges (n 1) 185-207; Jacques Derrida, Le problème de la genèse dans la philosophie de Husserl (PUF 2010); Jacques Derrida, La voix et le phénomène: Introduction au problème du signe dans la phénoménologie de Husserl (PUF 2016). On the absence of origin, see also Barthes, Essais critiques IV (n 6) 75.
} 
The consequences of such de-necessitating of originist thinking are wide-ranging for international legal thought and practice. Without anticipating Chapter 4 below, two of these consequences can be mentioned at a very general and abstract level. First, such de-necessitating of originist thinking entails that the forms of the international legal discourse should not be approached as having a source or an author. Indeed, the source and the author of a form always follow-rather than precede - the form. ${ }^{81}$ Second, there is not only nothing "prior" to forms but there is nothing "outside" the forms either. The "outside" of the forms of the international legal discourse is itself produced by forms and can thus not be outside it. ${ }^{82}$ In other words, the forms of the international legal discourse have no context, whether the context of their making or the context of the reading or invocation of the forms. The forms of the international legal discourse have no outside, for this outside is already in the forms by virtue of the latter's self-difference. The outside of the form-and thus the so-called context — can never be autonomously delineated and thought independently from those forms.

\subsection{De-necessitating the Quest for Content}

The sovereignty of forms similarly bears important consequences for the very idea of content-determination and interpretation as they are commonly understood in international legal thought and practice, and, more fundamentally, for deliverability thinking. It is submitted here that whether in its strong or mild version, deliverability thinking cannot withstand the sovereignty of forms that is foregrounded here. Indeed, as has been repeatedly indicated in the previous sections, the sovereignty of forms is premised on the postulation that no meaning is delivered by the forms of the international legal discourse. The sovereign forms of the international legal discourse thus strip interpretation of its hermeneutic dimension, ${ }^{83}$ a matter to which Chapter 4 returns. ${ }^{84}$ Simply said,

81 On the death of the author, see Barthes, Essais critiques IV (n 6) 63-69. Jonathan Culler speaks of the text being orphaned. See Jonathan Culler, Structuralist Poetics: Structuralism, Linguistics, and the Study of Literature (Ithaca 1975) 133. See the critical observations of Stanley Fish, 'With the Compliments of the Author: Reflections on Austin and Derrida' (1982) 8 Critical Inquiry 693.

82 On Derrida's famous claim that there is nothing outside the text in Derrida, Grammatologie (n 1) 225-226. See also the remarks of Bennington, Jacques Derrida (n 57) 83; Salmon, An Event, Perhaps (n 52) 143. With an emphasis on legal studies, see the remarks of Legrand, 'Understanding Understanding' (n 53) 80.

83 Derrida, Marges (n 1) 17; Barthes, Essais critiques IV (n 6) 47. On the earlier idea that the language is not at the service of signification but is signification itself, see Merleau-Ponty, Signes (n 27) 68-69, 379-80.

84 See Chapter 4, Section 1. 
any imputation of meaning is impossible. ${ }^{85}$ For the same reason, the identity of forms never raises a question of determinacy or indeterminacy. Indeed, a form never has a determinate or indeterminate identity but only bears the - always vanishing - traces of other forms within it.

The claim made here, and according to which the forms of the international legal discourse strip interpretation of its hermeneutic dimension for lack of any meaning or content to be interpreted, calls for two brief observations. First, it must be emphasized that the sovereignty of forms does not entail that the search for the meaning of forms is simply supplanted by a search for the meaning of forms' self-difference. Indeed, as was already indicated above, ${ }^{86}$ the forms' self-difference does not constitute yet another content that can possibly be extracted, interpreted, or created. Such traces of otherness within the selfsame are no surrogate for meaning. Actually, the moment that traces of the other forms come within purview, they are already caught in the deferral of meaning and have vanished. In that sense, the trace of otherness within the selfsame, that is self-difference, can never be apprehended, produced, given a content, and interpreted. The forms of the international legal discourse are at best a site of passage, that is, a place of perpetual transit. ${ }^{87}$ Second, it is equally important to highlight that the forms of the international legal discourse, as a site of passage, are not empty corridors. On the contrary, the forms of the international legal discourse are always in a state of saturation because of the constant deferral of meaning: forms' self-difference ensures that forms are always saturated with traces of those other forms to which meaning is deferred.

\subsection{De-necessitating the Quest for Reality}

The sovereignty of forms severely puts into question the abovementioned reifying thinking that dominates international legal thought and practice whereby forms are supposed to respond to or be anchored in a certain reality. In fact, by virtue of the sovereignty of forms, what the forms of the international legal discourse are supposed to respond to or be anchored in does not have a material existence outside and independent from forms. ${ }^{88}$ Said differently, the reality of forms, be it of the thing, the idea, the norm, the practice, the behavior, the institution, the discourse, and so on which the forms of the international legal

\footnotetext{
85 Legrand, 'Il n'y a pas de hors-texte' (n 49) 131.

86 See Chapter 1, Section 3.

87 Barthes, S/Z (n 57) 10-11; Barthes, L'aventure sémiologique (n 31) 13; Barthes, Essais critiques IV (n 6) 56, 73-75.

$88 \mathrm{Cf}$ the critique of reifying thinking in comparative law by Pierre Legrand, and especially of the postulation that the foreign exists positively apart from the discourse, see Legrand, 'Understanding Understanding' (n 53) 72-73.
} 
discourse represent, are anchored in, or respond to are never external to (and independent from) forms. From the perspective of the sovereignty of forms advocated here, the forms of the international legal discourse and the deferral of meaning should be deemed out of the order of experience. ${ }^{89}$

\section{THIS BOOK}

This book exposes the meaning-centrism of international legal thought and practice, sheds lights on the deferral of meaning by international legal forms, and elaborates on the implications of the sovereignty of forms. In doing so, this book ventures a new attitude toward textuality in international law. The discussion is organized as follows. Chapter 2 provides a series of illustrations of the main manifestations of meaning-centrism of international legal thought and practice, and especially of originist thinking, deliverability thinking, and reifying thinking that are witnessed therein. Chapter 3 illustrates how meaning is constantly deferred by the forms of the international legal discourse by virtue of their self-difference. Chapter 4 elaborates on the concrete implications of the sovereignty of forms and of the de-necessitating of meaning-centrism, especially with respect to interpretation, the international lawyer herself, the critical attitude, the study of history in international law, the exercise of comparison, the translation of international legal texts, and the practice of referencing.

At this preliminary stage, two caveats are warranted. First, this book, although it visibly draws on some post-structuralist thinkers, is no attempt to transpose the works of the latter in international legal thought. As will be further argued in Chapter 4, transposition is not a possibility. ${ }^{90}$ In fact, the works of these post-structuralist thinkers are, like all texts, caught in the infinite deferral of meaning, and thus have no pre-existing meaning that could be mechanically transposed to international law. For the sake of this book, such post-structuralist texts are at best an event whose experience by the author of these lines is caught, like everything else in this book, in the indefinite deferral of meaning. ${ }^{91}$

\footnotetext{
89 See gen. Derrida, Marges (n 1) 1-29.
}

90 See the remarks of David Wood, 'Introduction' in David Wood and Robert Bernasconi (eds), Derrida and Différance (Northwestern University Press 1988) xi. On the idea that post-structuralist critique cannot just be applied or transposed to law, see Schlag, 'The Politics of Form' (n 5) 1657. For a logo-centric treatment of Jacques Derrida and an attempt to translate his work for legal studies, see Balkin, 'Deconstructive Practice' (n 32).

91 On the idea of texts as events and happenings, see Chapter 4, Section 1. 
Second, it must be made clear that, whilst this book is an attempt to de-necessitate the dominant meaning-centrism of international legal thought and practice, this book itself cannot escape meaning-centrism..$^{92}$ De-necessitating the dominant meaning-centrism of international legal thought and practice does not entail a neutralization of meaning-centrism. Meaning-centrism remains at work throughout this book. For instance, the resort to notions of meaning, meaning-centrism, self-difference, trace, deferral of meaning, thinking, reader, interpreter, interpretation, international lawyer, international law, loyalty, and so on, although these words and idioms are themselves caught in meaning deferral, may denote a meaning-centric posture. ${ }^{93}$ The many idioms of ordinary language that this book resorts to ("it is argued," "it is submitted," "needless to say," "in other words," "as was said," and so on) are equally premised on an assumption of a pre-existing meaning. Meaning-centrism could similarly be found in this book as book. ${ }^{94}$ Indeed, a book inevitably presents itself as the neat, linear, totalizing, and systematic container of a pre-existing argument or thought which it is supposed to carry and deliver. ${ }^{95}$ And yet, a book's ambition to carry and deliver meaning - one would say "thoughts" - is always defeated, for meaning is deferred and made perpetually absent. The considerations and developments populating the following chapters as well as the format of their presentation thus remain part of the meaning-centric tradition they contest. For this reason, this book can be scrutinized in the very same way as it scrutinizes the dominant meaning-centrism of international legal thought and practice.

92 Derrida, Positions (n 27) 35, 56. See also Derrida, Ecriture (n 1) 46. On the idea that recuperative powers of logocentrism in legal studies must not be underestimated, see Schlag, 'The Politics of Form' (n 5) 1649.

93 Even the mobilization of certain authors and certain pieces of work in the footnotes denotes such a meaning-centric move although such authors and works are themselves caught in the deferral of meaning. See gen. Peter Goodrich, 'J.D.' (2005) 6 German Law Journal 15. See also Pierre Schlag, 'My Dinner at Langdell's' (2004) 52 Buffalo Law Review 851.

94 For an attempt to escape the meaning-centrism of the book through disruptive typographies, see Jacques Derrida, Glas (Galilée 1974); Jacques Derrida, La carte postale: De Socrate à Freud et au-delà (Flammarion 1980). Cf the attempt to escape the meaning-centrism of the law article by Amaya-Castro and El Menyawi, 'Moving Away' (n 32).

95 For some general remarks on the meaning-centric closure of a book, see Derrida, Positions (n 27) 11; Derrida, Grammatologie (n 1) 30-31; Derrida, Papier Machine (n 2) 27. On the idea that Derrida's Grammatology is about the end of the book, see Goodrich, 'Europe in America' (n 2) 2042; Florian Hoffmann, 'Epilogue: In Lieu of Conclusion' (2005) 6 German Law Journal 197. On the idea that every piece of writing has unity, see Brian Dillon, Essayism (Fizcarraldo Editions 2017) 15. On the linearity of international law books, see the remarks of Parfitt, International Legal Reproduction (n 22) 15 . 
This is also why this book, like any other international law book, is condemned to be born-dead, only to resuscitate each time it is read by a living being. ${ }^{96}$ And yet, notwithstanding the fact that de-necessitating the meaning-centrism of international legal thought and practice does not neutralize meaning-centrism, it is hoped that this book will be instrumental in breeding a new way of reading international law texts, one that ceases to consider them as a conveyer of pre-existing thoughts and arguments and that makes such works open spaces saturated with traces and where meaning is only passing, never stopping, and always vanishing.

96 Jacques Derrida, The Beast and the Sovereign, vol 2 (University of Chicago Press 2011) 131. 